\title{
Balancing University Teaching and Media Industry Needs: A Case Study of Teaching Finance and Economics News Translation
}

\author{
Wan $\mathrm{Hu}^{1} \&$ Xuquan Wang ${ }^{2}$ \\ ${ }^{1}$ School of Foreign Studies, Central University of Finance and Economics, Beijing, China \\ ${ }^{2}$ China Daily, Beijing, China \\ Correspondence: Wan Hu, 39 South College Road, Central University of Finance and Economics, Haidian District, \\ Beijing 100081, China. E-mail: huwan@cufe.edu.cn
}

Received: May 29, 2019

doi:10.5430/ijhe.v8n3p247
Accepted: June 17, 2019

Online Published: June 18, 2019

\begin{abstract}
This research uses case study research and employs a news translation module to analyse its synergic teaching method which includes a university teacher, an industry insider and translation learners. They, as the key stakeholders of the teaching and learning process, have their specific roles and continuously interact with each other. Through these interactions, actual trans-editing workflow is embedded into the university classroom. In order to examine the teaching effectiveness of such an innovative model, translation learners' responses and commentaries are carefully taken into consideration. A wider implication of this research is that translator trainers may have their own reflections on innovating teaching strategies via the integration of academia and the professional world.
\end{abstract}

Keywords: university-industry collaboration, innovative teaching model, curriculum design, news translation

\section{Introduction}

Since the new millennium, the traditional, teacher-centred methodologies in translator training have been gradually replaced by professionally-oriented, authentic, learner-centred, situated learning, or project-based learning approaches (Kiraly, 2000, 2005; Li \& Han, 2018; Li, Zhang \& He, 2015; Prieto-Velasco \& Fuentes-Luque, 2016).

These pioneering approaches, despite differences in terms of teaching ethos, content and executive mode, have some shared principles in training translators for the new era. Firstly, particular pedagogical techniques (e.g. situated, collaborative and project-based learning) are now used by many translator trainers to provide learners with real-life or quasi-professional work environments or tasks (AI-Shehari, 2017; Huertas Barros, 2011; Li, 2000). Secondly, introducing students with an authentic translation environment, assignments and materials are strongly advocated. For example, teachers may use texts which were translated from an actual situation (Mackenzie, 1998, p. 36). Students should also be informed of the translation brief, the type of readership as well as the clients' requirements, before conducting any translation assignments (Nord, 2018; Samuelsson-Brown, 2010). Furthermore, in the times of Web 4.0, Big Data and Artificial Intelligence, a translator's work may be more web and technology-based and therefore not limited within a written text. In this case, it is suggested to use technological and electronic resources in translator training which assists students to be more familiar with a future working environment, and to improve translation performance (Hirci, 2012). Thirdly, embedding a professional translator's practical experiences and perceptions into a university-based curriculum is another growing and beneficial trend. This can be achieved either through providing students with internship places in translation agencies, or by offering opportunities for professional engagement. For instance, professional competences, work experiences as well as translation difficulties can be introduced to students by invited professional translators. The ultimate goal of doing this is to "raise students' awareness of how to optimally meet job requirements" (Abdel Lalif, 2018, p. 11) by bridging the gap between learning and working environments.

In view of these teaching approaches, translator training has developed remarkably in terms of introducing professional elements into teaching. The specialised engagement has mainly focused on two-dimensional interaction, either between the teacher and students (e.g. real-life or highly simulated translation projects inside the classroom), or between professional translators and students (e.g. internship outside the classroom). However, there have been few research projects on establishing university-business (industry) teaching partnerships in translator training, which is in fact, quite prominent in other disciplines, such as business and engineering. 
Against such a context, this study endeavours to bridge this research gap by introducing a multi-dimensional approach, which includes the university teacher, an industry insider and students, in the teaching of a practical translation course. Students' evaluations have been taken into consideration to examine the validity and effectiveness of such a university-business partnership in Translation Studies. Findings generated from this paper aim to contribute authentic views and experiences to future pedagogy-oriented translation research.

\section{Modern Finance and Economics News Translation: A New Approach to Teaching with the Media Industry}

Translation of Finance and Economics News is a compulsory module included in a BA translation course at a key university in Beijing. This module is offered to Year 2 undergraduates and is considered to be the first regarding practical translation; it runs for an entire academic year. Furthermore, it was designed with establishing a university-business partnership. This has been achieved by fully responding to the current and predicted market needs. The module convenor and a senior trans-editor worked collaboratively via the editing platform 'iNews' to supervise students' translations regarding finance and economics bulletins. The iNews platform is part of the China Daily, a leading English-language newspaper in China, which includes both print and digital news media.

This university-industry partnership introduces the media requirements, along with authentic news translation assignments into training courses. It provides students with basic trans-editing concepts and professionally-oriented hands-on experience. Students benefit greatly by receiving guidance from both academia and the media profession. More specifically, students "register as translators on the iNews website, and translate or trans-edit news reports on a regular basis" (Hu, 2018, p. 178). Their translations are quality assured by the trans-editor. These high quality news items will become formal news articles, which will be published in the business section of the China Daily. The teacher is responsible for imparting translation theories, explaining translation pitfalls and summarising trans-editing techniques.

In this partnership, students are the focus in the teaching and learning process, the teacher plays a role as an "educational consultant" or as a "project coordinator" ( $\mathrm{Li}, 2013)$, while the trans-editor becomes an external examiner. These three stakeholders in the process, having their specific roles, regularly interact with each other. More specifically, the close interaction between the teacher and students provides them with the scaffolding for learning as well as invaluable study resources. The cooperation among students enable them to solve translation problems collaboratively and to have a deep understanding and intelligent application of knowledge. The teacher, after frequent communication with the trans-editor, is made aware of the evaluation principles and rationales used. The teacher then conveys the editor's revisions to students from the pedagogical perspective and in a more explicit way. The exchange between students and the trans-editor enables them to think about the purpose, methods and target readership of news translation. The ultimate purpose of doing this is to improve the readability of a trans-edited text and to enhance the broadcasting effect.

\section{Teaching Translation of Finance and Economics News: Essential Curricular Studies}

\subsection{Teaching Objectives and Intended Learning Outcomes}

An effective translation teaching procedure consists of formulating clear teaching objectives, designing teaching content and sequencing the materials accordingly, as well as designing both pedagogical and professional activities (González Davies, 2004; Kelly, 2005; Nation \& Macalister, 2010). Of these, the teaching objectives are of paramount significance as they determine the overall design of a course. There are two important dimensions in formulating the teaching objectives: firstly, the intended learning outcomes students' are expected to achieve; secondly, the specific competencies students are expected to acquire.

In this sense, the module of translating finance and economics news aims to provide students with a thorough overview of how to adapt to the target readership. This also includes how to deliver and complete a translation project, how to deal with translation problems that professional trans-editors encounter, and how to reflect on one's own translation work. These central components are carried out under the supervision from both the university teacher and the media industry insider.

After one year of study, students are expected to acquire the following learning outcomes: (1) to consolidate students' transferrable skills between English and Chinese languages; (2) to develop students' in and outgoing translation competencies; (3) to enhance students' knowledge and understanding of journalistic discourse, especially in the field of finance and economics; (4) to be familiar with the trans-editors' working environment; (5) to heighten students' project management and organisational skills. 


\subsection{The Sequencing for Teaching and Learning Activities}

In order to achieve the above teaching objectives and intended learning outcomes, both the university and the industry systemically planned the sequence of teaching and learning activities. They designed situated learning tasks and confirmed four main teaching procedures (see figure 1).

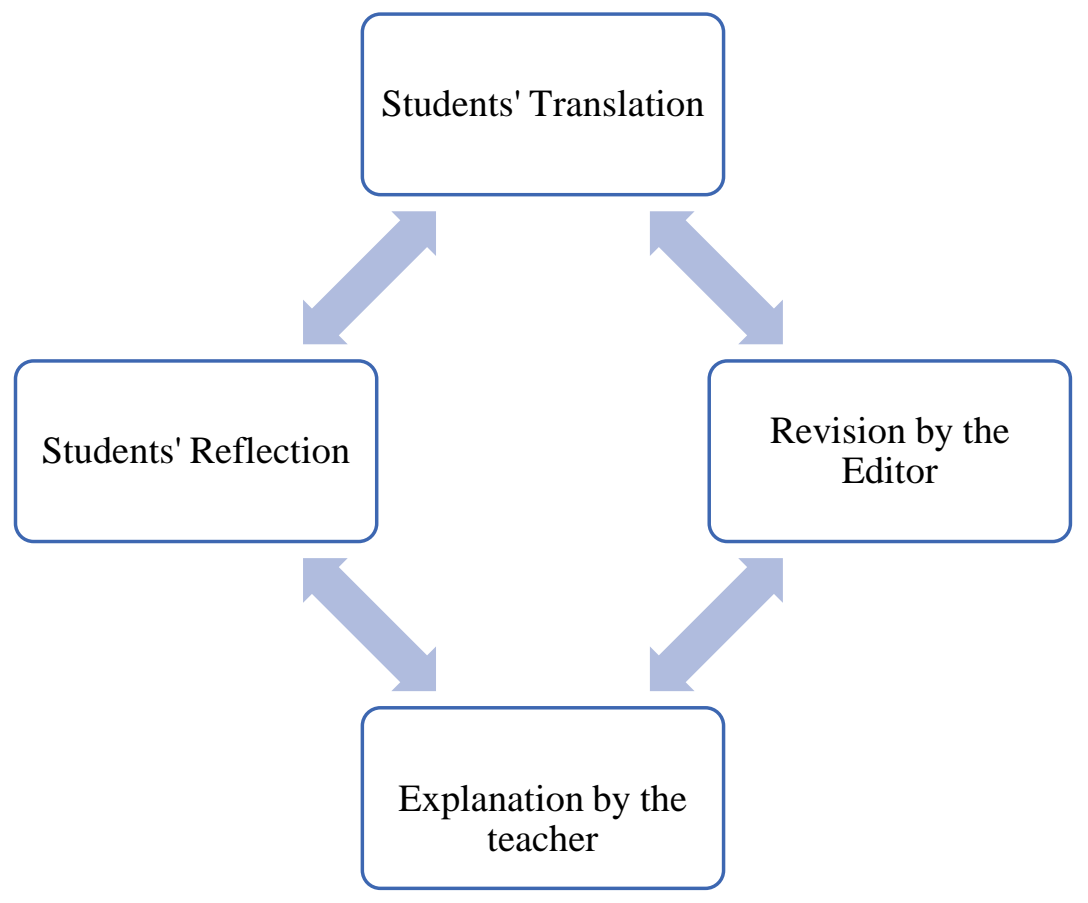

Figure 1. The Teaching Procedures

Firstly, the module convenor selects texts for students to translate. All the translation materials are authentic and timely. Students work in groups to complete each translation task collaboratively and rotate their roles (e.g. project leaders; student translators; student editors; web designers). The group leaders are suggested to verify and "quality assure' their group work before final submission.

Secondly, students submit their translations to the iNews platform for further revisions by the professional trans-editors. The professional revision criteria includes whether the translation offers a complete and precise rendition of the original text, whether the translation is appropriate to the style of the newspaper, whether the style and manner of the writing is localized within target culture conventions, and lastly, whether the translation reads like an original piece written in the target language ( $\mathrm{Hu}, 2018$, p. 180). Furthermore, if students' translations meet the above criteria, they would be published as news reports in Chinese.

Thirdly, the teacher compares students' original translation work with trans-editors' revisions, and then offers evaluations from the aspect of translation quality and translation effect. With regard to translation quality, the teacher mainly focuses on whether the source text is accurately understood and rendered, whether the translation is appropriate, and how long and complex sentences are dealt with. In terms of translation effect, the teacher makes comments on readership, register, and news conventions.

Finally, students write reflective learning journals based on trans-editors' revisions and the teacher's explanation. In order to help students reflect on their translating process more effectively, the teacher offers writing notes and guidelines. More specifically, students' learning journals present a review of the entire translating process, the translation challenges encountered and the students' accompanying strategies. Furthermore, it demonstrates the variance between students' work and the editors' revisions along with advice for future improvements. Other assistance could include a summary of financial terms and subject area knowledge.

\subsection{The Module Content: Balancing Theory, Practice and Work Placement}

After the formulation of the teaching procedures, the next step in the process is deciding what material should be included in the course, the individual lessons and logical sequencing for complete learning. 
When thinking and discussing the content of financial news translation, the course designers took the following three elements into consideration. Firstly, the teaching and learning materials should be at a suitable level for the students to grasp, covering both theory and practice. Secondly, the selected translation texts should be in line with the norms of iNews and the China Daily. Lastly, the materials are not only used for language and translation enhancement but also for the learning of subject matter, especially in finance and economics.

\subsubsection{Theoretical Concepts}

Before enrolling in this component, students have already studied the module Contrastive Studies and Translation between English and Chinese. Here, students have acquired prior knowledge regarding the differences between English and Chinese languages as well as basic translation techniques. However, they have limited knowledge in trans-editing theory and skills. It is therefore unrealistic to ask students to translate financial news immediately; instead, meta-theory and conceptual issues are introduced in the first few weeks. These include the principles of English news, linguistic and non-linguistic features of English news, as well as trans-editing norms and methods. At the same time, short-length news stories are provided for translation. In so doing, students may apply the theories into news translation practices, and to have a critical view of their own work (Pellatt \& Liu, 2010).

\subsubsection{Practical Translation: Finance and Economics News}

Finance and economics news mainly reports on issues such as "current trends in economic development and the fluctuation of financial markets" (Li, 2017, p. 97), which can cover a large number of subtopics. However, classroom teaching cannot incorporate all these subtopics, but can only focus on a few of them. The teacher and the trans-editor, after conducting careful research on the most frequent financial news topics, decided to focus their teaching in the following categories: the stock markets; mergers \& acquisitions, economic growth, financial markets, business and management, and finally, the global market. The selected news articles are mainly from the Wall Street Journal, the Financial Times, the Dow Jones and BBC business sections. After teaching three year groups, the total number of students' translations were roughly 500, 000 English words. Table 1 presents the selected finance and economics news translated by students.

Table 1. Students' translations on finance and economics news (selected)

\begin{tabular}{|c|c|c|}
\hline English Source Text (Headlines) & Chinese Target Text (Headlines) & Subtopics \\
\hline $\begin{array}{l}\text { One eye on China, Street Watching } \\
\text { the Fed }\end{array}$ & $\begin{array}{l}\text { 华尔街同时紧盯中国市场和美联 } \\
\text { 储会议 }\end{array}$ & Stock Market \\
\hline Microsoft to buy LinkedIn for $\$ 26 b n$ & $\begin{array}{l}\text { 微软进军职场社交 斥巨资 } 262 \\
\text { 亿美元收购领英 }\end{array}$ & Merger \& Acquisition \\
\hline Is China really growing at $6.9 \% ?$ & $\begin{array}{l}\text { 中国第三季度 GDP 增速真的是 } \\
6.9 \% \text { 吗? }\end{array}$ & Economic Growth \\
\hline $\begin{array}{l}\text { China's yuan gains IMF reserve } \\
\text { status }\end{array}$ & $\begin{array}{l}\text { IMF 接受人民币成为国际储备货 } \\
\text { 币之一 }\end{array}$ & Financial Markets \\
\hline $\begin{array}{l}\text { Starbucks laser-focused on China } \\
\text { market }\end{array}$ & 星巴克聚焦中国市场 & Business \& Management \\
\hline $\begin{array}{lcc}\text { IMF } & \text { meeting } & \text { drops } \\
\text { anti-protectionism pledge } & \end{array}$ & $\begin{array}{l}\text { IMF 删除“反对贸易保护主义”措 } \\
\text { 辞 }\end{array}$ & Global Trade \\
\hline
\end{tabular}

It is agreed by many European Scholars that a translator should translate texts from a foreign language into his/her first language. Nevertheless, there has been a rising demand for translating into major foreign languages in many countries (Hatim, 2005, pp. 164-168). China is such an example. According to Gile (2010, p. 17), with increasingly international exchanges in finance, technology, political dialogues and other sectors, the greater translation into English is especially needed in China. In addition, China is now in the process of building images in international affairs and as a consequence, is developing stronger presence and authority in the international arena. Translation has been given a significant role in promoting Chinese cultures and values to, and within other countries. The media, on the other hand, serves as an intermediary between China and the world. Considering both national strategy and the market needs, the teacher and the trans-editor decided to add a section of translating Chinese news into English from spring 2017. The students translated a raft of news reports in Chinese regarding China's interest rate hikes, Chinese educational company's IPO, and Chinese enterprises going global. Students, in this sense, are expected to learn to 
use idiomatic English and Western equivalent thinking patterns to report Chinese hot topics in finance and economics.

\subsubsection{Work Placement: Trans-Editing Economic News during China's "The Two Sessions"}

The National People's Congress and the Political Consultative Committees of China (here after noted as "the two sessions") hold meetings in Beijing every March. In China, this is the foremost political event of the year where nearly 6,000 delegates gather in Beijing for the occasion. During "the two sessions" period, the Chinese premier introduces the latest government working report, and journalists from various media organisations report China's political and economic policies. These include China's revised economic growth targets and the accompanying economic strategies. In order to help students build on the real-life experiences of professional trans-editors, the teacher and the trans-editor design a session of work placements for students, to trans-edit English news reports from the foreign sources for the China Daily newspaper. The students are mainly responsible for China-related economic comments, such as growth targets, fiscal policy and the defence budget. The professional trans-editors verify the quality of students' work and provide them with invaluable suggestions for future learning. Table 2 outlines students' trans-edited work during China's "the two sessions".

Table 2. Students' Trans-edited Reports during China's "The Two Sessions" (selected)

\begin{tabular}{ll}
\hline English Headlines & Chinese Headlines \\
\hline China's Leaders Put the Economy on Bubble Watch & 新的财政思路为中国经济转型护航 \\
$\begin{array}{l}\text { China sets itself a lofty growth target } \\
\text { China 'not heading for hard landing', says top }\end{array}$ & $\begin{array}{l}\text { 发改委主任表示中国经济不会硬着陆 } \\
\text { economic planner }\end{array}$ \\
$\begin{array}{ll}\text { Govt aims to pursue a more proactive, effective fiscal } \\
\text { policy }\end{array}$ & 中国政府力争更积极有效财政政策 \\
$\begin{array}{l}\text { China's finance ministry releases \$151 billion } \\
\text { defence budget }\end{array}$ & 外媒: 中国财政部公布 1510 亿美元国防预算 \\
Foreign experts offer their insights for report & 外国专家为中国政府工作报告建言献策
\end{tabular}

The trans-editing assignments required in this session are different from classroom-based translation practices in many aspects. Firstly, students may be required to carefully analyse and re-contextualise media coverage and to "either selectively translate the texts or to de-dramatize the text" (Cheng, 2011, p. 224). Abridgement, an important trans-editing method, which is frequently used in such assignments. Secondly, there is an issue of time pressure with deadlines. During the Chinese "the two sessions", journalists are expected to have the first coverage of a news story and to make all communication quicker (Holland, 2013, p. 336). The student trans-editors, therefore, are facing the pressure to "deliver translations as quickly as possible" (Cronin, 2005, p. 111). The economic topics during "the two sessions" cover issues such as economic restructuring, GDP growth rate, plans for economic development, and so forth. It is therefore important for student trans-editors to accurately transmit all the key terms as well as the data and other information. Additionally, student trans-editors also need to develop their abilities for analysing the entire economic context.

\section{The Effectiveness of University-Industry Partnership in Translation Courses: Students' Evaluations}

In the process of curriculum design and development, evaluation is an essential step to test the validity of a course. The results and feedback of an evaluation may provide input for course improvement and quality enhancement (Kelly, 2005; Nation \& Macalister, 2010). Evaluation is normally a cooperative activity which involves teachers, administrators, external examiners, students, or even experts from a state department of education (Ornstein \& Hunkins, 2009, p. 302). Of these, students' participation is of great importance for professional development, in that their learning experience can reflect "the effectiveness of various curricular components" (ibid., p. 303), and can check where the curriculum needs to be improved.

\subsection{Approaches to Gather and Analyse Students' Perceptions}

In order to fully reflect on a course, feedback from a pedagogical perspective was required from the students. To realise this aim, the two course designers (the teacher and the trans-editor) created an enquiry form with open-ended questions. The objective was to capture students' perceptions towards their learning as set out in the curriculum. Apart from gathering data from the enquiry form, the results of the student evaluations of teaching (SET) and students' reflective learning journals were carefully taken into consideration. The questions listed on the enquiry form centred on four 
elements: the effectiveness of the university-industry collaborative learning model, the effectiveness of teaching and learning activities, the acquisition of translation and/or translation-related competences, and the improvement of student learning.

Three student year groups (forty-eight students in total) offered detailed feedback regarding their learning experience of finance and economics translation. Of these forty-eight students, six were male (12.5\%) and forty-two were female $(87.5 \%)$. They were at their twenties, had similar educational background, and their years of learning translation were the same. All these students finished one-year learning of finance and economics news translation when they participated in this study.

\subsection{Results: Students' Evaluations on University-Industry Partnership in Translation Courses}

From the completed comments, the university-industry collaborative teaching was perceived as beneficial. Students also claimed that they had developed their translation competence, built up subject area knowledge competence, and increased their awareness of the professional world. The following are the most frequently mentioned aspects (see table 3).

Table 3. Students' evaluations on learning translation via university-industry collaborative teaching

\begin{tabular}{llll}
\hline Sequence & Parameters of Evaluation & Number of Frequency & Percentage \\
\hline 1 & $\begin{array}{l}\text { The teacher-student-editor interaction as a } \\
\text { reflective learning experience }\end{array}$ & $100 \%$ \\
2 & $\begin{array}{l}\text { Consolidating translation techniques } \\
3\end{array}$ & $\begin{array}{l}\text { Constructing subject area knowledge through } \\
\text { translation }\end{array}$ & 72 \\
4 & Enhancing career development and employability & & \\
\end{tabular}

\subsubsection{The Teacher-Student-Editor Interaction as a Reflective Learning Experience}

All the forty-eight students were positive about their learning under the supervision of both the teacher and the media industry insider. Students indicated that the intensive learning procedure of "(1) students' group translation — (2) trans-editor's revision — (3) teacher's explanation — (4) students' reflection" was of paramount significance for their translation learning. Each step in this procedure generated positive learning effects for all.

In regard to group translation, one of the first steps was to make students aware of the features of news translation. This resulted in the added benefit of laying the foundations for their own translating styles. Further, the collaborative translating environment enabled students to adopt multiple strategies, to solve difficulties encountered in the translation process. Students, through discussions with their peers, were able to generate different versions of the same source text, which then developed the students' abilities of using different translation methods.

Secondly, the trans-editor's revisions provided students with an opportunity for initial reflection. This, raised their consciousness in problem-solving and provided the groundwork for the classroom teaching in the next phase.

After carefully reading the trans-editor's feedback, students brought their perplexing problems into the classroom. The teacher's interpretation and analysis of both the students' work and the trans-editor's revisions, assisted students by offering a more profound understanding to the translating process.

Students became aware that they could gradually apply theoretical concepts of news translation into the trans-editing practice, which then enhanced their mastery of accompanying trans-editing skills. As one student mentioned:

This was the core step for students to accumulate knowledge and formulate their own translation system. (Jade)

With regard to the final step of writing the reflective learning journal, students re-examined the source text and their translations, consolidated their prior knowledge, and established links between each learning stage. Some students highlighted the effectiveness of such an interactive learning procedure, saying that:

This learning model was very effective for learning translation. We had to practice, think, give our own translations, analyse the proved translations, listen to the teacher's careful explanation, and reflect on the entire translating process afterwards. In this way, we had at least three intensive discussions about each text. We began to regard translation as more of a process instead of a product. This largely increased our self-awareness of difficulties in the translating process and provided some boost to our coping strategies accordingly. (Alisa, Michelle, Tina and Coco) 
According to the students, this interactive teaching model increased their self-motivation and confidence in learning translation, and enhanced their expectancy of success. As a whole, they found this type of translation learning stimulating and satisfying.

\subsubsection{Consolidating Translation Techniques}

After studying for one year, it was evident that students had made clear progress in producing target texts in line with the client's norms and the target readership (the client references to iNews). They also acquired a better understanding of the source text and then adopted appropriate techniques in order to translate to a professional level. The vast majority of the students claimed that they firstly developed, and then consolidated their translation techniques, after completing the large amount of translation and reflective exercises. For instance, some students clearly mentioned that they had a better understanding of translations strategies, methods and techniques:

......learned how to deal with texts of different lengths, how to analyse the underlying messages of the texts, and how to ensure cohesion and coherence in our translations. In addition, we found it less difficult translating news headlines, as well as long and complex sentences than before.

Another student, holding a very positive viewpoint, backed up the point by adding:

To be frank, this module largely developed my translation competence. The after-class exercise and in-class feedback increased my confidence in translation. I was impressed with my efficiency in translating texts, and I developed my ability to make any components of the translation project work effectively as a whole. Moreover, I had a better understanding of the differences between English and Chinese languages, and how these would affect the translating process. Finally, I even learned how to adopt appropriate techniques to translate financial terms and concepts. (Jade)

\subsubsection{Constructing Subject Area Knowledge through Translation}

As the module discussed in this study centred on translating financial and economic news — specialised texts, it is therefore necessary for students to "acquire sufficient basic knowledge to understand the major concepts" in the field of finance and economics (Kelly, 2005, p. 77). Most students reported that they became much more familiar with the knowledge of business, economics and finance through translating multiple news texts:

This was a very good way for me to get to know knowledge in the field of business and management. In addition to the translation, I also read many business case studies regarding the multinational companies encountered in the translation (e.g. Starbucks; LinkedIn). Research on these case studies also increased my interest and level of motivation. (Rain and Crystal)

Students, who enrolled in the module of translating finance and economics news, were learning Micro / Macro Economics at the same time. Several students raised the issue of networking modules, applying economic concepts into the translating process:

We had better acquisition of knowledge in finance and economics. Differing from the abstract knowledge learned in our economics modules, the knowledge included in the finance and economics news was more flexible. Translating finance and economics news required both subject content and solid language and translation skills. We had to fully understand the finance and economics knowledge embedded in the source text, and then interpret it into equivalent expressions in the target text. The whole translating process, in some sense, developed our subject area competence in the specialised field of finance and economics (Brown, Lawrence, Annie, Van and Jade).

\subsubsection{Enhancing Career Development and Employability}

Employability has become an increasingly important topic in today's university teaching (González-Davies \& Enríquez-Raído, 2016; Yorke \& Knight, 2006). On the one hand, this aims to provide university students with professional and marketplace skills toward a rewarding career. On the other hand, it supports students to develop a series of "knowledge, skills, behaviours, attributes and attitudes" which are in relation to their lifelong learning (Cole \& Tibby, 2013, cited in Rodríguez de Céspedes, 2017, p. 3).

In this study, many students stated that the knowledge and skills of news translation acquired during university study were appropriate for the requirements in the trans-editing profession. Their performance in the iNews internship proved that they had a much greater understanding of the English financial news and superior techniques in trans-editing. This was most evident when compared with students from other universities in the same year. Regarding employability skills, students' areas of growth were summarised in the following aspects. 
Firstly, in the process of communicating with the trans-editor, whether online or in person, students were not limited to just study translation theories or financial knowledge. Instead, they learned how to look at the translation from the perspective of professional trans-editors. This included essential skills, such as how to write a concise news headline, how to select sources, and how to frame the news in line with the stance and standards of the news agency.

Secondly, students felt that the work placement carried out during "the two sessions" gave them an opportunity to preview the working environment of professional trans-editors. This allowed the students to become familiar with the work cycle, in both print and digital news media. Moreover, they acquired the skillset of trans-editing, which is different in many ways from daily translation.

Thirdly, a large number of students considered that the difficulties in the process of translating finance and economics news, may also be encountered in other fields. The translation strategies and techniques they learned in this area can be transferred to cope with other text types. These skills were interlinked and supported their future translation learning after school.

Last but not least, many students stated that these intensive translating practices permitted them to enjoy a better acquisition of economic policies and financial knowledge. Armed with these insights, students felt a greater confidence to deal with future financial news articles of a complex and demanding nature. More importantly, they were given the prospect to pursue a career regarding both languages and financial knowledge. As several students suggested, they may apply for international projects in the Asian Infrastructure Investment Bank if there were employment vacancies, or work as journalists reporting finance and economics news.

In addition to the frequently mentioned areas of growth listed above (4.2.1 to 4.2.4), students also reported that this module helped them improve their information mining and research skills. Furthermore, this also enhanced their ability to think critically, and promoted collaborative learning with their fellow students.

Viewed from these evaluations, the full involvement of the teacher, students and the trans-editor made the translation practice not just assignments, but authentic, purposeful exercises that required deep thinking. Students happily developed a greater understanding of what they were learning in the teaching process. It was the 'coming together' of the three parties which complemented each other so well, delivering beneficial outcomes for all.

\section{Conclusion}

This research centred on pedagogical innovation when teaching a practical translation course. It introduced an innovative approach to imparting necessary skills in finance and economics news translation for the media industry. Within this approach, students learned news translation in an interactive environment with their peers, the teacher and a professional trans-editor. Students' formative evaluations demonstrated the effectiveness of university-industry collaborative teaching. They claimed that they had formed an overall understanding of how the media industry operates. They were also able to acquire translation competences, trans-editing, and problem-solving skills as well as enhanced communication abilities. These skillsets can be applied directly and proficiently in a specific work environment.

The industry inspired partnership investigated in this research may enlighten translator training and translation practice. For instance, the collaboration between the university and media industry provided a timely case study in response to the changing roles of university teaching under market pressure. Pedagogically, this learner-centred, industry-embedded teaching approach may provide insights for translator trainers and researchers with the qualities and shortcomings of this learning mode. Educators who are contemplating the integration of professional media needs in translation courses, or wish to optimise their teaching in the future, could be well served by this study.

It should also be noted that this pedagogy-focused translation research was conducted in a unique context (a key university in China), and research findings are mainly from qualitative data generated from students' evaluations. In the future, quantitative methods could be adopted to assess the teaching effectiveness of a course from the perspective of a greater sampling. Additionally, despite the fact that students were one of the key players in evaluating the curriculum content, they may be subjective or judgemental, as they have not received any training as evaluators. With regard to this evaluation, and improving teaching outcomes, it is essential to decide "who to assess" and "what to assess". This could be achieved by incorporating more players in the appraising process and clarifying the purpose, steps and focus of the evaluation. Finally, further investigations on the possibilities and application of university-collaboration in translation or language studies could be investigated, and how this collaboration, could trigger both research innovation and economic development. 


\section{References}

Abdel Latif, M.M. (2018). Towards a typology of pedagogy-oriented translation and interpreting research. The Interpreter and Translator Trainer, 12(3), 322-345. https://doi.org/10.1080/1750399X.2018.1502008

AI-Shehari, K. (2017). Collaborative learning: trainee translators tasked to translate Wikipedia entries from English into Arabic, The Interpreter and Translator Trainer, 11(4), 357-372. https://doi.org/10.1080/1750399X.2017.1359755

Cheng, W. (2011). Innovative subjectivity of transeditors in intercultural communication - a case study of the translated news of the 2008 Olympic Games. Language and Intercultural Communication, 11(3), 215-231. https://doi.org/10.1080/14708477.2010.549567

Cole, D., \& Tibby, M. (2013). Defining and Developing Your Approach to Employability: A Framework for Higher Education Institutions. York: Higher Education Academy.

Cronin, M. (2005). Burning the House Down: Translation in a Global Setting. Language and Intercultural Communication, 5(2), 108-119. https://doi.org/10.1080/14708470508668887

Gile, D. (2010). Chinese BTIs and MTIs-A golden opportunity. In W. Zhong \& B. Wang (Eds). Interpreting in China: New Trends and Challenges - Proceedings of the $7^{\text {th }}$ National Conference and International Forum on Interpreting (pp. 10-33). Beijing: Beijing Foreign Language Teaching and Research Press.

González Davies, M. (2004). Multiple Voices in the Translation Classroom. Amsterdam/Philadelphia: John Benjamins. https://doi.org/10.1075/btl.54

González Davies, M., \& Enríquez-Raído, V. (2016). Situated learning in translator and interpreter training: bridging research and good practice. The Interpreter and Translator Trainer, 10(1), 1-11. https://doi.org/10.1080/1750399X.2016.1154339

González, M. G., \& Díaz, M. T. V. (2015). Guided Inquiry and Project-Based Learning in the field of specialised translation: a description of two learning experiences, Perspectives: studies in translatology, 23(1), 107-123. https://doi.org/10.1080/0907676X.2014.948018

Hatim, B. (2005). Teaching and Researching Translation. Beijing: Beijing Foreign Language Teaching and Research Press.

Hirci, N. (2012). Electronic Reference Resources for Translators: Implications for Productivity and Translation $\begin{array}{lllll}\text { Quality. The Interpreter and Translator } & \text { Trainer, 6(2), 219-236. }\end{array}$ https://doi.org/10.1080/13556509.2012.10798837

Holland, R. (2013). News Translation. In C. Millán \& F. Bartina (Eds). The Routledge Handbook of Translation Studies (pp. 332-346). London and New York: Routledge.

Hu, W. (2018). Revisiting Translation Quality Assurance: A Comparative Analysis of Evaluation Principles between Student Translators and the Professional Trans-editor. World Journal of Education, 8(6), 176-186. https://doi.org/10.5430/wje.v8n6p176

Huertas Barros, E. (2011). Collaborative learning in the translation classroom: preliminary survey results. The Journal of Specialised Translation, 16, 42-60.

Kelly, D. (2005). A Handbook for Translator Trainers. Manchester: St. Jerome Publishing.

Kiraly, D. (2000). A Social Constructivist Approach to Translator Education. Empowerment From Theory to Practice. Manchester: St. Jerome Publishing.

Kiraly, D. (2005). Project-Based Learning: A Case for Situated Translation. Meta: Translators' Journal, 50(4), 1098-1111. https://doi.org/10.7202/012063ar

Li, D. (2000). Tailoring translation programmes to social needs: A survey of professional translators. Target, 12(1), 127-149. https://doi.org/10.1075/target.12.1.07li

Li, D. (2013). Teaching Business Translation: A Task-based Approach. The Interpreter and Translator Trainer, 7(1), 1-26. https://www.tandfonline.com/doi/abs/10.1080/13556509.2013.10798841

Li, D. (2017). News Translation: Principles and Methods ( $2^{\text {nd }}$ edition). Hong Kong: Hong Kong University Press.

Li, D., Zhang, C. \& He, Y. (2015). Project-based learning in teaching translation: students' perceptions. The Interpreter and Translator Trainer, 9(1), 1-19. https://doi.org/10.1080/1750399X.2015.1010357 
Li, X., \& Han, Q. (2018). Constructing an interpreter education model in light of the social constructivism and situated learning theory: Justifications and design. Journal of Xi'an International Studies University, 26(3), 62-68. https://doi.org/10,16362/j.cnki.cn61-1457/h.2018.03.012

Mackenzie, R. (1998). The place of language teaching in a quality-oriented translators' training programme. In K. Malmkjær (Ed.), Translation and Language Teaching: Language Teaching and Translation (pp. 15-20). Manchester: St. Jerome Publishing.

Nation, I.S.P., \& Macalister, J. (2010). Language Curriculum Design. London and New York: Routledge.

Nord, C. (2018). Translating as a Purposeful Activity: Functionalist Approaches Explained (2 ${ }^{\text {nd }}$ edition). London and New York: Routledge.

Ornstein, A. C., \& Hunkins, F. P. (2009). Curriculum: Foundations, Principles, and Issues. Boston: Pearson.

Pellatt, V., \& Liu, E. T. (2010). Thinking Chinese Translation: a course in translation method: Chinese to English. London and New York: Routledge. https://doi.org/10.4324/9780203849316

Prieto-Velasco, J. A., \& Fuentes-Luque, A. (2016). A collaborative multimodal working environment for the development of instrumental and professional competences of student translators: an innovative teaching experience. The Interpreter and Translator Trainer, 10(1), 76-91. https://doi.org/10.1080/1750399X.2016.1154344

Rodríguez de Céspedes, B. (2017). Assessing employability and enterprise responsibilities in the translation

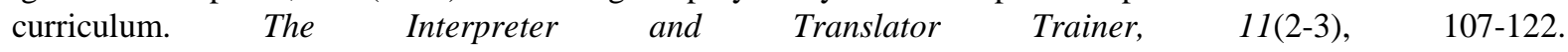
https://doi.org/10.1080/1750399X.2017.1344816

Samuelsson-Brown, G. (2010). A Practical Guide for Translators ( $5^{\text {th }}$ edition). Bristol, Buffalo and Toronto: Multilingual Matters. https://doi.org/10.21832/9781847692610

Yorke, M., \& Knight, P. (2006). Embedding Employability into the Curriculum. Higher Education Academy. https://www/heacademy.ac.uk/resource/embedding-employability-curriculum 